\title{
Small Intestinal High Grade B-Cell Lymphoma, Not Otherwise Specified
}

National Cancer Institute

\section{Source}

National Cancer Institute. Small Intestinal High Grade B-Cell Lymphoma, Not Otherwise

Specified. NCI Thesaurus. Code C96057.

A small intestinal high grade B-cell lymphoma with blastoid features or features between diffuse large B-cell lymphoma and Burkitt lymphoma which lacks MYC, BCL2, and BCL6 rearrangements. 